\title{
Gambaran Hiperbilirubinemia pada Bayi Aterm dan Prematur di RSUP Prof Dr. R. D. Kandou Manado
}

\author{
${ }^{1}$ Yulke R. Y. Rompis \\ ${ }^{2}$ Jeanette I. Ch. Manoppo \\ ${ }^{2}$ Rocky Wilar
}

\begin{abstract}
${ }^{1}$ Program Studi Pendidikan Dokter Fakultas Kedokteran Universitas Sam Ratulangi Manado
${ }^{2}$ Bagian Ilmu Kesehatan Anak Fakultas Kedokteran Universitas Sam Ratulangi manado Email: yrompis12177@yahoo.com
\end{abstract}

\begin{abstract}
Hyperbilirubinemia is an increase of blood bilirubin level due to physiological or non-physiologic factors, which is clinically characterized by jaundice. In neonates, their livers have not worked optimally, therefore, the process of glucuronidation of bilirubin does not occur optimally. This situation causes the predominance of unconjugated bilirubin in the blood. This study was aimed to obtain the profile of neonatal hyperbilirubinemia cases in the Pediatrics Department of Prof. Dr. R. D. Kandou Hospital Manado. We used medical record data of neonatal hiperbilirubinemia in aterm and premature neonates at the Pediatrics Department of Prof. Dr. R. D. Kandou Hospital di Bagian Ilmu Kesehatan Anak RSUP Prof. Dr. R. D. Kandou Hospital during 2014-2015. The results showed that there were 54 cases, consisted of 32 males (59.3\%) and 22 females (40.7\%). Among aterm neonates, mean direct bilirubin was $3.97 \mathrm{mg} / \mathrm{dL}$; mean indirect bilirubin was $11.76 \mathrm{mg} / \mathrm{dL}$; and mean total bilirubin was $15.69 \mathrm{mg} / \mathrm{dL}$. Meanwhile, among premature neonates, mean direct bilirubin was 0.87 $\mathrm{mg} / \mathrm{dL}$; mean indirect bilirubin was $12.48 \mathrm{mg} / \mathrm{dL}$; and mean total bilirubin was $13.35 \mathrm{mg} / \mathrm{dL}$. In conclusion, at the Pediatrics Department of Prof. Dr. R. D. Kandou Hospital Manado neonatal hyperbilirubinemia was more common in aterm neonates compared to premature neonates. Moreover, it is more common in males than in females.
\end{abstract}

Keywords: hyperbilirubinemia, bilirubin, aterm meonates, premature neonates

\begin{abstract}
Abstrak: Hiperbilirubinemia ialah terjadinya peningkatan kadar bilirubin dalam darah, baik oleh faktor fisiologi maupun non-fisiologi, yang secara klinis ditandai dengan ikterus. Pada neonatus, hati belum berfungsi secara optimal sehingga proses glukuronidasi bilirubin tidak terjadi secara maksimal yang menyebabkan dominasi bilirubin tak terkonjugasi dalam darah. Penelitian in bertujuan untuk mendapatkan gambaran hiperbilirubinemia pada bayi aterm dan prematur di RSUP Prof. Dr. R. D. Kandou Manado. Data penelitian diperoleh dari rekam medik kejadian hiperbilirubinemia pada bayi aterm dan prematur di Bagian Ilmu Kesehatan Anak RSUP Prof. Dr. R. D. Kandou periode 2014-2015. Hasil penelitian mendapatkan 54 kasus dengan diagnosis hiperbilirubinemia yang memenuhi kriteria inklusi penelitian, terdiri dari 32 pasien berjenis kelamin laki-laki (59,3\%) dan 22 berjenis kelamin perempuan (40,7\%). Pada bayi aterm, rerata bilirubin direk sebesar 3,97 mg/dL; rerata bilirubin indirek 11,76 $\mathrm{mg} / \mathrm{dL}$; dan rerata bilirubin total $15,69 \mathrm{mg} / \mathrm{dL}$. Pada bayi prematur, rerata bilirubin direk sebesar $0,87 \mathrm{mg} / \mathrm{dL}$; rerata bilirubin indirek $12,48 \mathrm{mg} / \mathrm{dL}$; dan rerata bilirubin total 13,35 mg/dL. Simpulan penelitian ini ialah kasus hiperbilirubinemia di Bagian Ilmu Kesehatan Anak RSUP Prof Dr. R. D. Kandou Manado lebih sering pada bayi aterm dibandingkan bayi prematur, dan lebih sering pada jenis kelamin laki-laki.
\end{abstract}

Kata kunci: hiperbilirubinemia, bilirubin, bayi aterm, bayi prematur 
Hiperbilirubinemia merupakan salah satu fenomena klinis yang paling sering ditemukan pada neonatus. Hiperbilirubinemia menyebabkan bayi terlihat kuning, keadaan ini timbul akibat akumulasi pigmen bilirubin yang berwarna kuning pada sklera dan kulit. ${ }^{1}$

Di Indonesia, ikterus masih merupakan masalah pada bayi baru lahir yang sering dihadapi tenaga kesehatan, terjadi pada sekitar $25-50 \%$ bayi cukup bulan dan lebih tinggi pada neonatus kurang bulan. Di beberapa rumah sakit pendidikan, antara lain RS Dr. Kariadi Semarang, insiden ikterus pada tahun 2003 sebesar 13,7\%; $78 \%$ di antaranya merupakan ikterus fisiologi dan lainnyanya ikterus patologis serta angka kematian terkait hiperbilirubinemia sebesar 13,1\%. Di Yogyakarta RS Dr. Sardjito melaporkan sebanyak $85 \%$ bayi cukup bulan sehat mempunyai kadar bilirubin diatas $5 \mathrm{mg} / \mathrm{dL}^{2}$

Pada masa transisi setelah lahir, hepar belum berfungsi secara optimal, sehingga proses glukuronidasi bilirubin tidak terjadi secara maksimal. Keadaan ini menyebabkan dominasi bilirubin tak terkonjugasi dalam darah. Pada kebanyakan bayi baru lahir, hiperbilirubinemia tak terkonjugasi merupakan fenomena transisional yang normal, tetapi pada beberapa bayi, terjadi peningkatan bilirubin secara berlebihan sehinggah bilirubin berpotensi menjadi toksik dan dapat menyebabkan kematian. Bila bayi tersebut dapat bertahan hidup pada jangka panjang akan menimbulkan sekuele neurologis (Kern icterus). ${ }^{3,4}$

Ketika janin masih berada dalam rahim, tugas membuang bilirubin dari darah janin dilakukan oleh plasenta. Hati janin tidak perlu membuang bilirubin. Ketika bayi lahir, maka tugas ini langsung diambil alih oleh hati. Karena hati belum terbiasa maka diperlukan beberapa minggu untuk penyesuaian. Selama hati bayi bekerja keras untuk menghilangkan bilirubin dari darah, tentu saja jumlah bilirubin yang tersisa akan terus menumpuk di tubuh. Karena bilirubin berwarna kuning, maka jika jumlahnya sangat banyak, kulit dan sklera tampak kuning (ikterus).,
Bayi aterm akan memroduksi bilirubin 8-10 $\mathrm{mg} / \mathrm{kgBB} / \mathrm{hari}$, sedangkan orang dewasa sekitar 3-4 mg/kgBB/hari. Peningkatan produksi bilirubin pada bayi baru lahir disebabkan masa hidup eritrosit bayi lebih pendek dibandingkan orang dewasa, peningkatan degradasi heme, turnover sitokrom yang meningkat, dan juga reabsorbsi bilirubin dari usus yang meningkat. ${ }^{5,7}$ Dengan demikian, setiap bayi yang mengalami ikterus harus dibedakan apakah ikterus yang terjadi merupakan keadaan yang fisiologis atau patologis, serta dimonitor apakah mempunyai kecenderungan untuk berkembang menjadi hiperbilirubinemia yang berat. $^{6,7}$ Melihat tingginya insiden peningkatan kadar bilirubinemia pada bayi maka peneliti ingin mengetahui apakah terdapat perbedaan kadar bilirubin serum antara bayi aterm dan prematur.

\section{METODE PENELITIAN}

Penelitian di dilaksanakan di Bagian Ilmu Kesehatan Anak RSUP Prof Dr. R. D. Kandou Manado pada bulan Desember 2015. Jenis penelitian ini ialah deskriptif dengan desain potong lintang.

Sampel ialah bayi aterm dan prematur di Bagian Ilmu Kesehatan Anak RSUP Prof Dr. R. D. Kandou Manado periode 20142015. Data penelitian diperoleh dari rekam medik kejadian hiperbilirubinemia pada bayi aterm dan prematur di Bagian Ilmu Kesehatan Anak RSUP Prof. Dr. R. D. Kandou Manado periode 2014-2015. Analisis data dilakukan melalui pengolahan data secara komputerisasi dengan menggunakan Microsoft Excel. Hasil penelitian disajikan dalam bentuk tabel distribusi frekuensi dan persentase.

\section{HASIL PENELITIAN}

Berdasarkan hasil penelitian ini didapatkan 54 kasus dengan diagnosis hiperbilirubinemia yang memenuhi kriteria inklusi penelitian, terdiri dari 32 pasien berjenis kelamin laki-laki $(59,3 \%)$ dan 22 berjenis kelamin perempuan $(40,7 \%)$.

Tabel 1 memperlihatkan bahwa berdasarkan status kelahiran didapatkan status kelahiran aterm $(81,5 \%)$ lebih banyak 
dibandingkan dengan status kelahiran prematur $(18,5 \%)$.

Tabel 2 menampilkan kasus hiperbilirubinemia pada bayi laki-laki aterm sebanyak 26 pasien dan yang prematur sebanyak 6 pasien sedangkan pada bayi perempuan aterm didapatkan sebanyak 18 pasien dan yang prematur sebanyak 4 pasien.

Tabel 3 menunjukkan bahwa rerata bilirubin direk pada bayi aterm sebesar 3,97 $\mathrm{mg} / \mathrm{dL}$ (nilai minimum $0,10 \mathrm{mg} / \mathrm{dL}$ dan maksimum $30,89 \mathrm{mg} / \mathrm{dL}$ ); rerata bilirubin indirek sebesar $11,76 \mathrm{mg} / \mathrm{dL}$ (nilai minimum $3,20 \mathrm{mg} / \mathrm{dL}$ dan nilai maksimum $24,90 \mathrm{mg} / \mathrm{dL}$ ); dan rerata bilirubin total sebesar 15,69 mg/dL (nilai minimum 5,91 $\mathrm{mg} / \mathrm{dL}$ dan nilai maksimum 46,16 mg/dL).
Nilai bilirubin pada bayi prematur yaitu rerata bilirubin direk sebesar $0,87 \mathrm{mg} / \mathrm{dL}$ (minimum 0,14 mg/dL dan maksimum 1,63 $\mathrm{mg} / \mathrm{dL}$ ); rerata bilirubin indirek sebesar $12,48 \mathrm{mg} / \mathrm{dL}$ (minimum 7,02 mg/dL dan maksimum 23,18 $\mathrm{mg} / \mathrm{dL}$ ); dan rerata bilirubin total sebesar 13,35 $\mathrm{mg} / \mathrm{dL}$ (minimum 7,64 mg/dL dan maksimum $24,81 \mathrm{mg} / \mathrm{dL})$.

Tabel 1. Deskripsi karakteristik sampel berdasarkan status kelahiran

\begin{tabular}{ccc}
\hline $\begin{array}{c}\text { Status } \\
\text { kelahiran }\end{array}$ & $\begin{array}{c}\text { Jumlah } \\
(\mathbf{n})\end{array}$ & Persentase \\
\hline Aterm & 44 & 81,5 \\
Prematur & 10 & 18,5 \\
Jumlah & 54 & 100 \\
\hline
\end{tabular}

Tabel 2. Perbandingan jumlah sampel hiperbilirubinemia pada jenis kelamin dan status kelahiran

\begin{tabular}{cccc}
\hline Hiperbilirubinemia & Laki-laki & Perempuan & Total \\
\hline Aterm & 26 & 18 & 44 \\
Prematur & 6 & 4 & 10 \\
Total & 32 & 22 & 54 \\
\hline
\end{tabular}

Tabel 3. Deskripsi nilai rerata bilirubin berdasarkan status kelahiran

\begin{tabular}{lccc}
\hline & \multicolumn{2}{c}{ Hiperbilirubinemia } & \\
& $\begin{array}{c}\text { Bilirubin direk } \\
(\mathrm{mg} / \mathrm{dL})\end{array}$ & $\begin{array}{c}\text { Bilirubin indirek } \\
(\mathrm{mg} / \mathrm{dL})\end{array}$ & $\begin{array}{c}\text { Total } \\
(\mathrm{mg} / \mathrm{dL})\end{array}$ \\
\hline Aterm & 3,97 & 11,76 & 15,69 \\
Prematur & 0,87 & 12,48 & 13,35 \\
\hline
\end{tabular}

\section{BAHASAN}

Hiperbilirubinemia merupakan salah satu fenomena klinis yang paling sering ditemukan pada neonatus. Hiperbilirubinemia menyebabkan bayi terlihat ikterus yang diakibatkan akumulasi pigmen bilirubin yang berwarna kuning pada sklera dan kulit. ${ }^{1} \quad$ Etiologi hiperbilirubinemia antara lain infeksi, inkompatibilitas resus dan golongan darah, kongenital, dan hipotiroid. ${ }^{8,9}$ Bayi aterm adalah bayi yang lahir setelah kehamilan 40 minggu tetapi tidak lebih dari 42 minggu sedangkan bayi prematur adalah bayi yang lahir dengan usia kehamilan <37 minggu. Kelahiran prematur merupakan penyebab mortalitas, dan morbiditas, dan kecacatan jangka panjang. Bayi prematur berisiko tinggi menderita kecacatan bahkan kematian. ${ }^{7}$

Hiperbilirubinemia atau ikterus pada bayi dapat dibedakan menjadi fisiologis dan non-fisiologis. Ikterus fisiologis umumnya terjadi pada bayi baru lahir bila kadar bilirubin tak terkonjugasi pada minggu pertama $>2 \mathrm{mg} / \mathrm{dL}$. Pada bayi cukup bulan yang mendapat susu formula, kadar bilirubin akan mencapai puncaknya sekitar 6-8 $\mathrm{mg} / \mathrm{dL}$ pada hari ketiga kehidupan dan kemudian akan menurun cepat selama 2-3 hari diikuti dengan penurunan yang lambat sebesar $1 \mathrm{mg} / \mathrm{dL}$ selama 1 sampai 2 minggu. Terjadinya ikterus fisiologis tidak disebabkan oleh faktor tunggal tapi kombinasi dari berbagai faktor yang berhubungan dengan 
maturitas fisiologis bayi baru lahir., ${ }^{2,6}$ Ikterus non-fisiologis adalah ikterus yang terjadi sebelum usia 24 hari, dan bertahan setelah 8 hari pada bayi cukup bulan atau setelah 14 hari pada bayi kurang bulan. ${ }^{10}$

Berdasarkan data jenis kelamin, hiperbilirubinemia pada bayi baru lahir terbanyak pada jenis kelamin laki-laki yaitu sebanyak 32 kasus $(59,3 \%)$ sedangkan jenis kelamin perempuan sebanyak 22 kasus $(40,7 \%)$. Hasil ini sejalan dengan penelitian oleh Henry-Harry dan Trotman ${ }^{11}$ yang juga mendapatkan terbanyak kasus hiperbilirubinemia pada jenis kelamin laki-laki dibandingkan perempuan (61\% vs 39\%). Penelitian serupa yang dilakukan oleh Nurani $^{12}$ di RSU Dr. Hasan Sadikin Bandung melaporkan 8,04\% dari 2571 neonati yang lahir pada tahun 2014 menderita hiperbilirubinemia dengan persentasi laki-laki $(56,9 \%)$ lebih tinggi daripada perempuan. Neonatus yang lahir aterm dengan berat badan lahir rendah memiliki kemungkinan lebih besar terkena hiperbilirubinemia $(55,2 \%) .{ }^{13}$ Berbeda halnya dengan penelitian yang dilakukan oleh Tioseco et $\mathrm{al}^{13}$ yang justru mendapatkan kasus hiperbilirubinemia terbanyak pada jenis kelamin perempuan sebanyak 433 kasus dan laki-laki sebanyak 403 kasus, walaupun tingkat kadar bilirubin pada jenis kelamin laki-laki lebih tinggi dibandingkan perempuan.

Dennery et $\mathrm{al}^{14}$ dalam penelitiannya menyatakan bahwa kadar bilirubin di atas $25 \mathrm{mg} / \mathrm{dL}$ dapat mengakibatkan keadaan bayi yang buruk. Kadar bilirubin yang tinggi berpeluang mengakibatkan Kern icterus yang dapat membahayakan bayi sampai berujung pada kematian. ${ }^{15}$

Berdasarkan data status kelahiran, kasus hiperbilirubinemia paling banyak terdapat pada status kelahiran aterm sebanyak 44 kasus $(81,5 \%)$ sedangkan pada status kelahiran prematur sebanyak 10 kasus $(18,5 \%)$. Hasil ini sejalan dengan penelitian yang dilakukan oleh Veni ${ }^{15}$ yang mendapatkan kasus hiperbilirubinemia terbanyak pada status kelahiran aterm sebanyak 57 kasus dan prematur sebanyak 21 kasus. Namun, hasil penelitian yang dilakukan oleh Reza ${ }^{16}$ mendapatkan bahwa bayi prematur lebih banyak mengalami ikterus dibandingkan dengan bayi aterm (37 vs 11).

Pada penelitian ini didapatkan kadar bilirubin pada bayi aterm yaitu rerata bilirubin direk $(3,97 \mathrm{mg} / \mathrm{dL})$ lebih tinggi daripada bayi prematur $(0,87 \mathrm{mg} / \mathrm{dL})$, demikian pula rerata bilirubin total $(15,69$ $\mathrm{mg} / \mathrm{dL}$ ) lebih tinggi daripada bayi prematur $(13,35 \mathrm{mg} / \mathrm{dL})$, sedangkan rerata bilirubin indirek $(11,76 \mathrm{mg} / \mathrm{dL})$ lebih rendah daripada bayi prematur $(12,48 \mathrm{mg} / \mathrm{dL})$.

Berdasarkan jenis kelamin dan status kelahiran, didapatkan perbandingan hiperbilirubinemia pada bayi laki-laki yang aterm dan preterm ialah 26:6 sedangkan perbandingan hiperbilirubinemia pada bayi perempuan yang aterm dan preterm ialah 18:4. Hasil ini sejalan dengan penelitian yang dilakukan oleh Rajan ${ }^{17}$ yang melaporkan perbandingan hiperbilirubinemia pada bayi laki-laki aterm dan preterm 76:56 dan perbandingan pada bayi perempuan yang aterm dan preterm 76:56.

Hasil penelitian retrospektif yang dilakukan di Poliklinik Ilmu Kesehatan Anak RSUP Prof. Dr. R. Kandou periode Januari 2014-Desember 2015 mendapatkan total sebanyak 54 kasus bayi baru lahir dengan diagnosis hiperbilirubinemia. Jumlah ini masih lebih sedikit bila dibandingkan dengan penelitian yang dilakukan oleh Kamal et al $^{18}$ yang mendapatkan sebanyak 124 kasus selama periode JuliDesember 2011, dimana 24 kasus merupakan kasus fisiologis, 84 kasus karena tidak diberikan ASI, 5 kasus karena masalah menyusui, 5 kasus karena prematur, dan 6 kasus dikarenakan proses patologis.

Limitasi penelitian ini ialah jumlah sampel yang terbatas disamping keterbatasan waktu penelitian ini.

\section{SIMPULAN}

Berdasarkan hasil penelitian ini dapat disimpulkan bahwa kasus hiperbilirubinemia di Bagian Ilmu Kesehatan Anak RSUP Prof Dr. R. D. Kandou Manado lebih sering pada bayi aterm dibandingkan bayi prematur, dan lebih sering pada jenis 
kelamin laki-laki.

Pada penelitian selanjutnya diharapkan untuk ditelusuri riwayat kehamilan ibu dari bayi yang mengalami hiperbilirubinemia di RSUP Prof Dr. R. D. Kandou Manado.

\section{DAFTAR PUSTAKA}

1. Wong RJ, Stevenson DK, Ahlfors CE, Vreman HJ. Neonatal jaundice: Bilirubin physiology and clinical chemistry. NeoReviews 2007;8:58-67.

2. Blackburn ST. Bilirubin metabolism. Maternal, Fetal, and Neonatal Physiology, A Clinical Perspective (3rd ed). Saunder. Missiouri: Saunders, 2007.

3. Hutahaean B, Putranti AH. Neurodevelopmental disorder risk in babies with history of hyperbilirubinemia. Pediatrica Indonesiana. 2008;48(2):938.

4. Hansen TWR. Neonatal jaundice. EMedicine. Available from: URL:www.emedicine. medscape.com/article/974786overview. Last update: 15 juni 2011.

5. Halemek LP, Stevenson DK. Neonatal jaundice and liver disease. In: Fanaroff AA, Martin RJ, editors. NeonatalPerinatal Medicine. Disease of the Fetus and Infant (7th ed). St Louis: Mosby Inc, 2002; p.1309-50.

6. Sukadi A. Hiperbilirubinemia. In: Kosim MS, Yunanto A, Dewi R, Sarosa GI, Usman A. Buku Ajar Neonatologi (1st ed). Jakarta: Ikatan Dokter Anak Indonesia, 2010; p. 147.

7. Alan DH, Lauren N, Murphy G, Neri L. Current Diagnosis and Treatments in Obstetric and Gynecology. United States: McGraw-Hill Companies, 2007.

8. Porter ML, Dennis BL. Hyperbilirubinemia in term newborn. American Familiy Physician. 2002;65:599-606.

9. Gomella TL, Cunningham MD, Eyal FG, Zenk KE. Hyperbilirubinemia. In: Gomella TL, editor. Neonatology: Management Procedures, On-call Problems, Disease and Drugs. New York: Lange Medical Book/McgrawHill co, 2004; p. 381-95.

10. Martin CR, Cloherty JP. Neonatal hyperbilirubinemia. In: Cloherty JP, Eichenwaald EC, Stark AR, editors. Manual of Neonatal Care (5th ed). Philadelphia: Lippincott Williams \& Wilkins, 2004; p. 11.185-221.

11. Henry-Harry C, Trotman H. Epidemiology of neonatal jaundice at the University Hospital of the West Indies. 2012. Available from: : http://caribbean.scielo.org/pdf/wimj/ v61n1/07.pdf

12. Nurani NB, Kadi FA, Rustini T. Incidence of neonatal hyperbilirubinemia based on their characteristics at Dr. Hasan Sadikin General Hospital Bandung Indonesia. Althea Medical Journal. 2017;4(3):431-4.

13. Tioseco JA, Aly H, Milner J, Patel K, ElMohandes AA. Does gender effect neonatal hyperbilirubinemia in lowbirth-weigth infants. Pediatr Crit Care Med. 2005;6(2):171-4.

14. Dennery PA, Seidman DS, Stevenson DK. Neonatal hyperbilirubinemia. N Engl J Med. 2015;344(8):581-90.

15. Veni DV. The study on the effect of gender on serum bilirubin concentration in infants with neonatal hyperbilirubinemia. Int $\mathrm{J}$ Pharma Biosci. 2013;4:603-8.

16. Reza S. Perbedaan kejadian ikterus neonatorum antara bayi prematur dan cukup bulan pada bayi dengan berat badan lahir rendah di RS PKU Muhammadiyah Surakarta. Surakarta: Fakukltas Kedokteran Universitas Muhammadiyah Surakarta; 2016.

17. Rajan N. Kommu P.R.K. Krishnan L. Mani M. Significant hyperbilirubinemia in near-term and term newborns: a case-control study. J Clin Neonatol. 2017;6(3):220-4.

18. Kamal S, Sayedda K, Ahmed K. Breast non feeding: main cause of neonatal hyperbilirubinemia in areas adjoining Shri Ram Murti Smarak Institute of Medical Sciences, a tertiary care hospital, Bareilly. National Journal of Physiology, Pharmacy \& Pharmacology. 2012;2(2):108-12. 